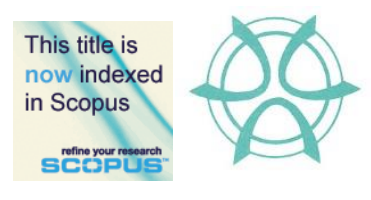

PLANNING MALAYSIA:

Journal of the Malaysian Institute of Planners

VOLUME 15 VOLUME 1 (2017), 319 - 326

\title{
ETHICS \& VALUES IN CONSTRUCTION INDUSTRY FROM ISLAMIC PERSPECTIVE
}

\author{
Fatma Al-Zahraa Sami ${ }^{1}$, \& Asiah Abdul Rahim² \\ ${ }^{1,2}$ Kulliyyah of Architecture \& Environmental Design \\ INTERNATIONAL ISLAMIC UNIVERSITY MALAYSIA
}

\begin{abstract}
The purpose of this paper is to explore the principles of Islamic ethics to be applied in construction projects by establishing Islamic ethical practices to improve project performance. In an Islamic system, ethics and construction business are inextricably linked. This paper aims primarily to identify the ethics in general and from the Islamic perspective, and to identify the principles of Islamic ethics in construction projects. The methodology of was content analysis of peer-reviewed empirical studies published in academic journals. In addition, specialist texts to review the principles of Islamic ethics in construction projects in order to give an overview of main ethics theories. This paper will discuss the impact of Islamic ethics on performance jobs and project outcomes. Finally, this study also shows how construction companies could adapt the Islamic ethics and create Islamic ethical work climate in their projects and in society as well. In conclusion, implementation of the recommended solutions can minimize unethical acts in the construction projects.
\end{abstract}

Keyword: Islamic ethics, ethics and values, construction industry and Islamic perspective, Al-Quran, Al-Sunnah

Date Received: $30^{\text {th }}$ April 2016

Date of Acceptance: $30^{\text {th }}$ October 2016 
Fatma Al-Zahraa Sami, \& Asiah Abdul Rahim

Ethics \& Values in Construction Industry from Islamic Perspective

\section{INTRODUCTION}

Different researchers give different definitions of ethics. A partial reason of the collapse of a number of construction projects in the past was probably the failure to follow ethical values as propagated by Islam. Failure of construction projects has led the Western societies to develop their own sets of work ethics for professional involved in construction projects. However, these sets of ethics were developed based on human intellectual capacities without looking into what the divine religions might have to say about them, although some of these man-made ethics are in conformity with what Islam or any other divine religion might have regarding them.

In recent years, attempts have been made to develop Islamic work ethics for professionals. One of such attempt is the book written by Abdi Omar Shuriye and Ahmad Faris Ismail. This research paper intends to deduce the principles of ethics and values for construction projects from Islamic sources, i.e. the texts of the Qur'an and Hadith of the Prophet (PBUH), so that this set of ethics would represent the Islamic values and perspective. This paper also explores the impact of embracing Islamic work ethics towards job performance and project outcomes. Finally, this paper puts forward several suggestions to reduce ethical issues in construction projects in the future.

\section{LITERATURE REVIEW}

\section{Ethic \& Islamic Ethic}

Ogbonna and Ebimobowei (2011) state that ethic and values is reflected in the rule that a man uses to govern his/her actions and the personal standard by which a person distinguishes the correct from the wrong. Islamic work ethics are the yearnings of the relations between the individuals themselves and their conduct at work in light of Islamic principles and fundamentals. Islamic work ethics stress on two things; (i) to accomplish every task with the best of an individual's capacity and (ii) to perform the task to please Almighty Allah alongside satisfying essential socio-economic needs. However, Islamic ethic incorporates the outer and inner parts of individual's life (Ibn Manzur, 1990; Miqdad Yaljin, 1973).

Beekun and Badawi (2005) analyse Islamic ethic from a standard perspective. Their essential finding asserted that Islamic ethic could not be isolated from a Muslim's day-to-day life. The Islamic ethical system is fair, balanced, just and benevolent, and looks to respect the rights of both primary and secondary stakeholder's without taking into consideration abuse, nepotism and other human ills. Beekun and Badawi (2005) additionally emphasise that humankind must not overlook his/her part as God's steward or vicegerent on earth.

In Islamic context, ethical framework is revealed from the teachings of the Quran and the Sunnah. Islamic ethic manages all aspects of human life. It 
manages relationships between man and Allah, man and his fellow man and other elements and creatures of the universe, and man and his inmost self (Hanafi \& Sallam, 1997). Besides, the objectives of Islam itself are not fundamentally materialistic. They depend on Islamic ideas of human prosperity and great life that underline fraternity and financial equity, and require an adjusted fulfilment of both material and needs of all people.

Additionally, Islamic ethic is also known as akhlak. Akhlak is the Islamic values, which have been specified in the Quran and executed by Prophet Muhammad (PBUH). Primarily, there are two (2) types of akhlak, bad or good. Islam underlines the imperative of honing good akhlak in all parts of human life and realizes it as one of the purpose of sending His messengers (Shaharuddin, 2005). Prophet Muhammad (PBUH) said: "I have been sent only for the purpose of perfecting the qualities of good akhlak" (Imam Malik). Beekun and Badawi (2005) state that the term most closely related to firmly identify with ethic in the Quran is khuluq. Allah says in the Quran, "And thou (standest) on an exalted standard of character." (68:4).

The Quran additionally utilizes an entire cluster of terms to portray the idea of goodness, for example, khayr (goodness), birr (uprightness), qist (equity), 'adl (equilibrium and justice), haqq (truth and right), ma'ruf (known and approved) and taqwa (piety). Devout activities are depicted as salihat and irreverent activities are portrayed as sayyiat.

\section{The Principles of Islamic Ethics in Construction Projects}

\section{Adl and Qist (Justice and Equal)}

Muhammad et al. (2008) suggest that Justice as Equity or 'Adl intends to treat individuals similarly is a pre-imperative of decency and equity. It is an equiponderant implementation of obligations and rights. Allah says in the Quran with regard to justice,

"Allah commands justice, the doing of good and liberality to kith and kin. He forbids all shameful deeds and injustice and rebellion; he instructs you, that ye may receive administration." (16:90)

In construction projects, the standard of justice applies both figuratively and literally. As far as relationship between project manager and his subordinates, the standards of justice infers that managers should exercise fair and equal treatment to all professionals (workers) paying little respect to gender, physical appearance, race, religion and political belief. Surely, experience, skills and attitude will decide the standings of the professionals (workers). Furthermore, Islam completely dismisses the act of bias and cronyism that lead to unfairness in procuring workers and in their promotion. Indeed, professionals ought to be picked or promoted based on their level of experience, academic qualification, 
Fatma Al-Zahraa Sami, \& Asiah Abdul Rahim

Ethics \& Values in Construction Industry from Islamic Perspective

job competency and, in addition, their good qualities (Shaharuddin, 2005). It is intriguing that another significance of "Adl is equity and equilibrium. As can be seen from the above citation of the Quran, a balanced transaction between stakeholders and construction companies is likewise evenhanded and just. Generally, Islam dislikes man's affinity for rapaciousness and his love for possessions (Beekun, 2005).

\section{Amanah (Trust)}

Trust is a key to constructive interpersonal connections in different settings since it is fundamental to how we communicate with others (McKnight \& Chervany, 1996). Ahmad (1995) points out that the acknowledgment of God's will by carrying on ethically is a piece of man's trusteeship and an obligation that he has taken upon himself to fulfil. More significantly, the wealth and other resources that mankind has access to are not his, but rather have been credited to him by God as instruments to fulfill the obligations of the trusteeship. Without a doubt, trust is accentuated in the Qur' an and Hadith. Allah says in the Quran,

"If ye are on a journey, and cannot find a scribe, a pledge with possession (may serve the purpose). And if one of you deposits a thing on trust with another, let the trustee (faithfully) discharge his trust, and let him fear his Lord. Conceal not evidence; for whoever conceals it, his heart is tainted with sin. And Allah knoweth all that ye do." (2: 283)

The Prophet (PBUH) specified the sigificance of trust as,

"Any ruler who has been entrusted with the affairs of a group of Muslims and who dies as a dishonest ruler, to him paradise is forbidden by Allah.".

Islam considers human life and assets as a trust rested on men by Allah. Subsequently, every project manager is in charge of the professionals (workers) and other resources with whom he is depended upon. Trust is particularly imperative for Muslim stakeholders in construction industry as result of the need to make profit and the enticements to upgrade the characteristics of their project or service during construction period. The project manager ought to treat all project resources as a heavenly trust. In this manner, the partner or administrator ought to make the most productive and socially alluring utilization of the project resources. The project activities ought to not harm the society or the natural environment. In reality, Islam underlines man's role towards the natural environment by making him in charge of his surroundings as Allah's vicegerent.

\section{Ihsaan (Benevolence)}

Ihsan means capability, fineness or charitableness in managing other. Muhammad et al. (2008) describe ihsaan as "a demonstration which benefits persons other than those from whom the demonstration continues with no 
commitment". The concept of benevolence is additionally frequently repeated in the Quran and the Hadith. Allah says,

Spend your wealth for the cause of God, and be not cast by your own hands to ruin; and do good. Lo! God loves those who behave with ihsan." (2:195)

The Prophet (PBUH) is reported to have said that,

"The inmates of Paradise are three types: one who wields authority and is just and fair; one who is truthful and has been endowed with power to do good deeds; and the person who is merciful and kind-hearted towards his relatives and to every pious Muslim, and who does not stretch out his hand in spite of having a large family to support." (Sahih Muslim).

Absence of justice in project construction causes damages and aggravates peace and harmony, however the absence of benevolence does not harm anybody. It suggests a more liberal treatment than what equity requires (Hasanuzzaman, 2003). Aside from justice, the relationship between project managers and professionals (workers) ought to be on the basis of benevolence.

\section{Ikhlas (Sincerity)}

Sincerity is most usually comprehended to be truthful in word and act. Additionally, sincerity can be characterized as the quality or state of being genuine; honesty of mind or intention; and devoid of hypocrisy, false pretence or disguise (Muhammad et al., 2008). Islam has accentuated ikhlas as we see in Quran and Hadith. Allah says,

"So woe to the worshippers, who are neglectful of their Prayers, Those who (want but) to be seen (of men), But refuse (to supply) (even) neighbourly needs." (107: 4- 7)

The Prophet (PBUH) said, in respect to sincerity,

"Actions are but intention and every man shall have but which he intended. Thus he whose migration was for Allah and His messenger, and he whose migration was to achieve some worldly benefit or take some woman in marriage, his migration was for that for which he migrated."

Hence, the execution of obligations requires that all professionals in construction projects work with sincerity. Establishing sincerity in the construction projects can enhance the professionals' effectiveness in job implementation resulting in higher productivity. Furthermore, such ethical code additionally debilitates control or misuse of others for individual reasons (Ahmad, 1995). Thus, a sincere professional is not anticipated to swindle resources, create mischief and exploit others deliberately. 
Fatma Al-Zahraa Sami, \& Asiah Abdul Rahim

Ethics \& Values in Construction Industry from Islamic Perspective

\section{IMPACT OF ISLAMIC ETHICS ON JOB PERFORMACE AND PROJECT OUTCOMES}

Earlier studies show that there is a positive relationship between Islamic ethics and job performance because Islamic ethics forms a constitutive part of a Muslim employee's belief system (Haroon, Zaman \& Rehman, 2012; Hayati \& Caniago, (2012); Marri et al., 2012; Batool, Gul \& Shahzad, 2013; Yousef, 2001). As a result, professionals who view their work environment in harmony with Islamic teachings and the ethical values are more satisfied in performing their duties. Consequently, this increases their intrinsic motivation to work. According to Daft and Marcic (2013, p. 400) "a positive attitude toward one's job" is called job satisfaction.

Also, Manan, Kamaluddin ad Puteh Salin (2013) explain that Islamic notion of considering work as a worship can make professionals become further motivated to work hard with higher rate of efficiency and effectiveness, which in turn benefits the organization both in the long and short run. Moreover, studies also reported that Islamic ethics has a positive significant correlation with project outcomes (Abbasi, Rehman \& Bibi, 2011: Yesil, Sekkeli \& Dogan, 2012).

\section{CONCLUSION}

In conclusion, this paper gives a review of the concept of ethic from Islamic perspective, in relation to construction projects. This paper provided the empirical proof of the positive relationship of Islamic ethics with job performance and project outcomes, but literature review revealed a number of issues. One of the major issues is that the review of the literature did not provide any theoretical arguments and reasoning as to how such a relationship exists. Therefore, this paper suggests that future studies into Islamic work ethics, especially in construction work ethics, to work on building strong logical arguments and theoretical studies by supporting their hypothesis and results. Moreover, future researchers are also recommended to build Islamic framework to in order to structure the values and principles of ethics in construction projects. 


\section{REFERENCES}

Abbasi, A. S., Rehman, K. U., \& Bibi, A. (2011). Islamic work ethics: How it affects business performance. Actual Problems of Economics, 126(12), 312.

Abdul Rahman, H., Saimon, M. A., \& Ali, A. S. (2009). Professional ethics in the construction industry of an Islamic country: clients' perspective. Construction in the Muslim World Conference, October 21-23, 2009, Kuala Lumpur, Malaysia.

Ahmad, M. (1995). Business ethics in Islam. Islamabad: The International Institute of Islamic Thought, Islamabad.

Badawi, J. (2005). Toward a spirituality for the contemporary organization. In Bridging the Gap between Spirituality and Business (pp. 66-79). Santa Clara, CA: Santa Clara University.

Batool S. M. K., Gul A., \& Shahzad, K. (2013). Combined effects of ethical leadership and Islamic work ethics (IWE) on organizational commitment and job satisfaction. Journal of Islamic Business and Management, 3(1), 35-49.

Beekun, R. I., \& Badawi, J. A. (2005). Balancing ethical responsibility among multiple organizational stakeholders: The Islamic perspective. Journal of Business Ethics, 60, 131-145.

Daft, R. L., \& Marcic, D. (2013). Understanding management (9th ed.). Stamford, USA: Cengage Learning.

Hanafi, A.A. \& Sallam, H. (1997). Business ethics: An Islamic perspective. In F. R. Faridi (Ed.), Islamic principles of business organisation and management. Kuala Lumpur: S. Abdul Majeed \& Co.

Hasanuzzaman, S. M. (2003) Islam and business ethics. London: Institute of Islamic Banking and Insurance.

Haroon, M., Zaman, H. F., \& Rehman, W. (2012). The relationship between Islamic work ethics and job satisfaction in healthcare sector of Pakistan. International Journal of Contemporary Business Studies, 3(5), 6-12.

Hayati, K., \& Caniago, I. (2012). Islamic work ethic: The role of intrinsic motivation, job satisfaction, organizational commitment and job performance. Procedia-Social and Behavioral Sciences, 65, 272-277.

Ibn Manzur (1990). Lisan al-`Arab (Vol.10). Beirut: Dar Sadir.

Manan, S. K., Kamaluddin, N., \& Puteh Salin, A. S. A. (2013). Islamic work ethics and organizational commitment: evidence from employees of banking institutions in Malaysia. Journal of Social Sciences and Humanities, 21(4), 1471-1489.

Marri, M. Y. K., Sadozai, A. M., Zaman, H. M. F., \& Ramay, M. I. (2012). The impact of Islamic work ethics on job satisfaction and organizational commitment: a study of agriculture sector of Pakistan. International Journal of Business and Behavioral Sciences, 2(12), 32-45.

McKnight, D. H., \& Chervany, N. L. (1996). The meaning of trust. Retrieved from http://misrc.umn.edu/ wpaper/WorkongPapers/9604.pdf

Miqdad Yaljin (1973). Al-Ittijah al-Akhlaqi fi al-Islam. Mesir: Maktabah al-Khanji.

Mohammed, A. (2005). The relationship between Islamic rules and accountants' ethics. Unpublished manuscript. Yemen: Hadhramout. 
Fatma Al-Zahraa Sami, \& Asiah Abdul Rahim

Ethics \& Values in Construction Industry from Islamic Perspective

Muhammad, M. Z., Ilias, A., Ghazali, M. F., Abdullah, R. C., \& Amin, H. (2008). An analysis of Islamic ethics in small and medium enterprises (SMEs). Unitar EJournal, 4(1), 46-58.

Ogbonna, G., \& Ebimobowei, A. (2011). Ethical compliance by the accountant on the quality of financial reporting and performance of quoted companies in Nigeria. Asian Journal of Business Management, 3(3), 152-160.

Shaharuddin, A. (2005). Islamic business ethics: A managerial perspective. In Proceedings of the Malaysian Finance Association 7th Annual Conference. Kuala Terengganu: UiTM.

Yesil, S., Sekkeli, Z. H., \& Dogan, O. (2012). An investigation into the implications of Islamic work ethic (IWE) in the workplace. Journal of Economics and Behavioral Studies, 4(11), 612-624.

Yousef, D. A. (2001). Islamic work ethic - A moderator between organizational commitment and job satisfaction in a cross-cultural context. Personnel Review, $30(2), 152-169$. 